\title{
Monoclonal antibodies for Streptomyces lividans and their use for immunomagnetic capture of spores from soil
}

\author{
Anil Wipat, ${ }^{1}+$ Elizabeth M. H. Wellington ${ }^{2}$ and Venetia A. Saunders ${ }^{1}$
}

Author for correspondence: Venetia A. Saunders.

1 School of Biomolecular Sciences, Liverpool John Moores University, Liverpool L3 3AF, UK

2 Department of Biological Sciences, University of Warwick, Coventry CV4 7AL, UK

\begin{abstract}
Monoclonal antibodies were produced to Streptomyces lividans spore surface antigens. One particular hybridoma cell line, 43H6, produced a monoclonal antibody that reacted exclusively with Streptomyces cluster group 21 in an enzyme-linked immunosorbent assay (ELISA). Antibody $43 \mathrm{H} 6$ was found to be of subclass IgG1, kappa light chain. Western blot (immunoblot) analysis revealed that $43 \mathrm{H} 6$ recognized a major outer spore polypeptide of about $37000 \mathrm{Da}$. The epitope was stably maintained in S. lividans spores over at least seven sporulation cycles on laboratory medium and for at least 14 weeks in sterile soil systems. The species group specificity of antibody $43 \mathrm{H} 6$ was exploited in the development of an immunocapture technique for the isolation of streptomycetes from soil. Magnetic beads coated with antibody $43 \mathrm{H} 6$ were mixed with soil samples seeded with $\mathbf{S}$. lividans spores. Spore-bead complexes were recovered using magnets. Treatment of beads with blocking agents and the inclusion of detergents in the recovery system lessened non-specific binding of spores to beads and improved recovery. In buffer solutions decreasing the spore concentration increased the recovery values for a fixed bead concentration. At a spore concentration of $5 \times 10^{7} \mathrm{ml}^{-1}$ the recovery was $4.3 \%$ whilst at $5 \times 10^{2} \mathrm{ml}^{-1}$ it was $76 \%$ for a fixed bead concentration of $0.6 \mathrm{mg} \mathrm{ml}^{-1}$. Using a bead concentration of $2 \mathrm{mg}$ per $10 \mathrm{~g}$ soil, approximately $30 \%$ of the target spore population of $10^{6}$ c.f.u. was recovered from sterile soil and $4 \%$ from non-sterile soil. This method offers a rapid means of selectively recovering and concentrating Streptomyces spores from soil samples.
\end{abstract}

Keywords: immunocapture, magnetic beads, spore surface antigens, Streptomyces lividans, soil, streptomycetes

\section{INTRODUCTION}

The availability of selective detection and recovery methods is an important prerequisite for exploring the fate of micro-organisms released into the environment. Immunological techniques have long been employed for the detection and identification of micro-organisms in clinical situations and in turn in soil, water and other environmental samples (Strayer \& Tiedje, 1978; Gates \& Pham, 1979; Wright et al., 1987; Levasseur et al., 1992). The application of immunological methods to the detection of genetically manipulated micro-organisms in environmental samples is relatively recent (for example

† Present address: Department of Microbiology, University of Newcastle upon Tyne, The Medical School, Framlington Place, Newcastle, NE2 4HH, UK.

Abbreviation: mAb, monoclonal antibody.
Morgan et al., 1989; Mason \& Burns, 1990; Morgan et al., 1991; Ramos-González et al., 1992). An advantage of immunological techniques is that they can be used for capture of specific organisms using magnetic polystyrene beads coated with appropriate antibodies (Morgan et al., 1989, 1991). In order to investigate the application of immunological methods to the detection and recovery of specific streptomycetes from the environment it is first necessary to isolate an appropriate antibody and to characterize and assess the suitability of its target antigen. Streptomycetes exist in soil mainly as spores or hyphal fragments (Mayfield et al., 1972). However during periods of nutrient elevation the mycelium may be present in significant amounts (Cresswell et al., 1992). Since survival in soil is most likely achieved as spores, antibodies directed against Streptomyces spore surface antigenic determinants are more applicable to immunological detection in the environment. It is now well recognized that the growth 
Table 1. Actinomycete strains

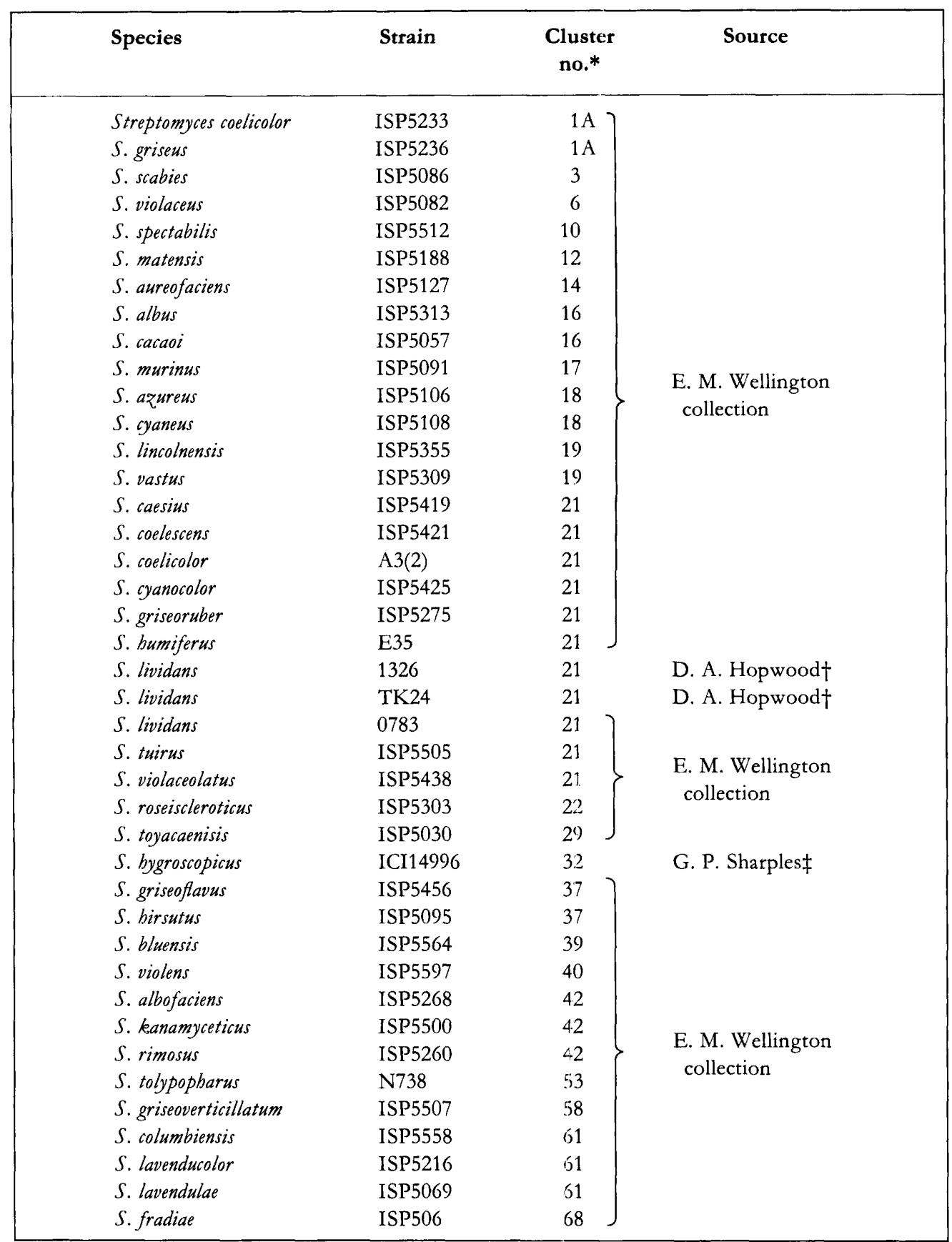

* Cluster group in accordance with Williams et al. (1983).

†D. A. Hopwood, John Innes Institute, Norwich, UK.

$\ddagger$ G. P. Sharples, School of Biomolecular Sciences, Liverpool John Moores University, Liverpool, UK.

environment of bacteria markedly influences phenotypic expression of surface characters (Smith et al., 1991; Nelson et al., 1991). Thus stability of the antigenic determinant is an important consideration in the development of an effective detection technique.

To date, studies on the immunology of streptomycetes have been very limited. Antisera have been raised against mycelium of Streptomyces spp. for use in taxonomic studies of species groups (Cross \& Spooner, 1963; Ridell \& Williams, 1983; Ridell et al., 1986). However, the specificity and continuous production of monoclonal antibodies ( $\mathrm{mAbs}$ ) make them more appropriate for use in the development of selective recovery and enrichment techniques.

This paper reports the production and characterization of $\mathrm{mAbs}$ to spore surface antigens of Streptomyces lividans and 
Table 2. Microbial strains other than Streptomyces

\begin{tabular}{|lll|}
\hline Species & Strain & \multicolumn{1}{c|}{ Source } \\
\hline Bacillus cereus & LPCC(B1) & LPCC* \\
B. megaterium & LPCC(B2) & LPCC \\
B. subtilis & LPCC(B3) & LPCC \\
B. stearothermophilus & LPCC(B3) & LPCC \\
Eschericbia coli & HB101 & LPCC \\
E. coli & ED8654 & C. Winstanley† \\
Trichoderma viride & LPCC(T2) & LPCC \\
Penicillium chrysogenum & LPCC(P1) & LPCC \\
Fusarium culmorum & LPCC(F1) & LPCC \\
\hline
\end{tabular}

* LPCC, Liverpool John Moores University microbiology culture collection.

†C. Winstanley, Genetics \& Microbiology Dept, University of Liverpool, UK.

\section{Table 3. Bacterial plasmids}

\begin{tabular}{|cll|}
\hline Plasmid & Characteristics* & Reference or source \\
\hline pIJ486 & tsr & Ward et al. (1986) \\
pIJ673 & $t s r$ aph $v p h$ & T. Keiser (unpublished) \\
pNW4 & $t s r \lambda_{\mathrm{L}} \times y l E$ & Wipat et al. (1991) \\
\hline
\end{tabular}

*tsr, aph, vph: resistance to thiostrepton, neomycin, viomycin respectively; $\lambda p_{\mathrm{L}}$, lambda promoter leftward; $x y / E$, gene. for catechol 2,3-dioxygenase.

the use of such antibodies in the immunological capture of streptomycete spores from soil. The capture technique utilized magnetic polystyrene beads coated with $\mathrm{mAb}$, to provide a large surface area for the attachment of $S$. lividans spores. Stable bead-spore complexes were attracted towards a strong magnet and subsequently recovered.

\section{METHODS}

Microbial strains and plasmids. The microbial strains are listed in Tables 1 and 2. Bacterial plasmids are described in Table 3. The plasmid pNW4 is a derivative of $\mathrm{pIJ486} \mathrm{(Ward} \mathrm{et} \mathrm{al.,} \mathrm{1986)}$ containing a cloned $x y l E$ gene expressed from the lambda $p_{\mathrm{L}}$ promoter. Streptomyces strains were routinely cultured on R2YE medium (Hopwood et al., 1985) at $28^{\circ} \mathrm{C}$ for $5 \mathrm{~d}$ or in YEME broth (Hopwood et al., 1985) at $28^{\circ} \mathrm{C}$ for $48 \mathrm{~h}$. Bacillus spp. were cultured aerobically either on nutrient agar plates or in nutrient broth at $37^{\circ} \mathrm{C}$ for $48 \mathrm{~h}$. Fungal strains were cultured on Potato dextrose agar plates at $28^{\circ} \mathrm{C}$ for $60 \mathrm{~h}$.

Antigenic purification and mAb production. S. lividans 1326(pI 673) spores were purified by density gradient centrifugation prior to use as antigen for $\mathrm{mAb}$ production. Crude spore suspensions, prepared as described by Hopwood et al. (1985), were resuspended in $40 \%(\mathrm{w} / \mathrm{w})$ sucrose and layered on to $40 \%: 50 \%: 60 \%(\mathrm{w} / \mathrm{w})$ sucrose step gradients. Gradients were centrifuged at $79700 \mathrm{~g}$ for $1 \mathrm{~h}$ at $20^{\circ} \mathrm{C}$ using a Sorvall OTD65B centrifuge and a TST 41.14 swinging bucket rotor $(6 \times 12 \mathrm{ml})$. The band of spores forming at the $40 \%: 50 \%$ interface was harvested, added to $20 \mathrm{ml}$ sterile distilled water and centrifuged at $2800 \mathrm{~g}$ for $10 \mathrm{~min}$ at $4{ }^{\circ} \mathrm{C}$. This process was repeated twice in order to wash the spores. Spores were resuspended in phosphate-buffered saline, $\mathrm{pH} 7.0$ [PBS; $8.5 \%$ (w/v) $\mathrm{NaCl} ; 3.9 \%$ (w/v) $\mathrm{NaH}_{2} \mathrm{PO}_{4} ; 13.4 \%$ (w/v) $\left.\mathrm{Na}_{2} \mathrm{HPO}_{4}\right]$. Female BALB/c mice ( 8 to 12 weeks old) were immunized intraperitoneally with a suspension of $200 \mu \mathrm{g}$ (total protein) intact $S$. lividans $1326(\mathrm{pI}$ J673) spores in $150 \mu \mathrm{l}$ sterile PBS and $150 \mu \mathrm{l}$ Freund's incomplete adjuvant. Intraperitoneal immunization was repeated after 4 and 6 weeks using the same inoculum and the serum titre of each mouse to intact $S$. lividans 1326(pIJ673) spores was determined by enzyme-linked immunosorbent assay (ELISA). Three days before the intended fusion date mice that showed suitable serum titres were inoculated with $200 \mu \mathrm{g}$ spores in sterile PBS alone. The mice were then killed and their spleens removed for fusion. Mouse spleen cells and NS1 myeloma cells were fused with $50 \%(\mathrm{w} / \mathrm{v})$ polyethylene glycol (Boehringer Mannheim) by the method of Clark \& Waldmann (1985). ELISA was used to screen the hybrid supernatants for the presence of specific antibodies. Positive hybridoma cell lines were cloned by limiting dilution using the method of Harlow \& Lane (1988). mAb was purified from tissue culture supernatant on a protein A affinity column (Pharmacia).

SDSPAGE and Western blot analysis. Spore polypeptides for analysis were prepared by alkaline sodium dodecyl sulphate (SDS) treatment and trichloroacetic acid precipitation as described by Guijarro et al. (1988). SDS-PAGE was performed on $10 \%(\mathrm{w} / \mathrm{v})$ slab gels as described by Laemmli (1970). Western transfer of polypeptides from SDS-PAGE gels was carried out by the method of Towbin $e t$ al. (1979) using an electrophoretic transfer apparatus. Following transfer to nitrocellulose membrane, immunoblotting with $\mathrm{mAb} 43 \mathrm{H} 6$ was carried out using standard techniques and developed colorometrically with 4chloro-1-naphthol (Harlow \& Lane, 1988).

Determination of epitope stability. Stability of the spore antigenic determinant of S. lividans 1326(pIJ673) was assessed on laboratory media and in sterile soil microcosms. For studies in vitro, S. lividans 1326 (pI J673) was continually subcultured on R2YE medium at $28^{\circ} \mathrm{C}$. Subculturing was performed in triplicate for seven sporulation cycles, each time using single colonies from the previous culture. Spore suspensions prepared from each generation were quantified by viable count and the reactivity of $\mathrm{mAb} 43 \mathrm{H} 6$ with the spores was assayed by ELISA. For studies in soil, spores from S. lividans 1326(pIJ673) were prepared as suspensions from R2YE plates as described by Hopwood et al. (1985). Soil was obtained from a wheat field site in Warwick, UK, as described previously (Wellington et al., 1990). Soil microcosms were prepared by wetting $100 \mathrm{~g}$ aliquots of autoclaved unamended soil in glass, foil capped, $300 \mathrm{ml}$ beakers to $20 \%(\mathrm{w} / \mathrm{w})$ with sterile distilled water and seeded with $10^{7}$ S. lividans $1326(\mathrm{pI} \mathrm{J673)} \mathrm{spores} \mathrm{in} 1 \mathrm{ml}$ sterile distilled water. The microcosms were incubated at $28^{\circ} \mathrm{C}$ for 14 weeks prior to spore isolation by soil homogenization and sucrose density gradient centrifugation. Soil $(100 \mathrm{~g})$ was homogenized with $100 \mathrm{ml}$ sterile distilled water and the resulting mixture centrifuged at $2400 \mathrm{~g}$ for $5 \mathrm{~min}$ at $4{ }^{\circ} \mathrm{C}$ to pellet heavy material. The resulting pellet was re-homogenized with a further $100 \mathrm{ml}$ sterile distilled water. The process was repeated and the supernatants from all three pooled and centrifuged at $2400 \mathrm{~g}$ for $10 \mathrm{~min}$ at $4{ }^{\circ} \mathrm{C}$ to give a pellet. This pellet was resuspended in $40 \%(\mathrm{w} / \mathrm{w})$ sucrose and spores isolated by centrifugation in a $40 \%(\mathrm{w} / \mathrm{w})$ and $60 \%(\mathrm{w} / \mathrm{w})$ step sucrose gradient at $79700 \mathrm{~g}$ for $1 \mathrm{~h}$ at $20^{\circ} \mathrm{C}$. The spores banded at the $40 \%-60 \%$ interface and were harvested and washed in PBS, prior to examination by ELISA.

Immunomagnetic particle preparation. Immunomagnetic particles (Dynabeads M450 sheep anti-mouse $4.5 \mu \mathrm{m}$, Dynal 


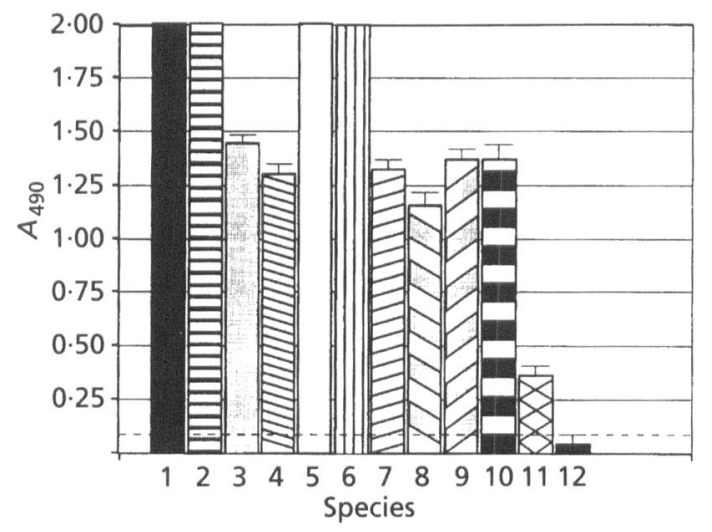

Fig. 1. Affinity of $\mathrm{mAb} 43 \mathrm{H} 6$ for spores from $\mathrm{S}$. lividans 1326 (plJ673) and closely related species (from cluster 21). The affinity of mAb $43 \mathrm{H} 6$ for spores from S. lividans 1326(p|J673) and closely related Streptomyces spp. (from cluster 21) was determined by ELISA. Negative control wells were coated with S. lividans 1326 spores as antigen and utilized PBS in place of $\mathrm{mAb} 43 \mathrm{H} 6$. The broken line near the base of the figure indicates the negative cut-off point [calculated as the mean plus three standard deviations of the readings from three negative control wells (Ngo \& Lenhoff, 1985; Tjissen, 1985)]. Error bars indicate the standard error from three replicate samples. 1, S. lividans 1326(p|J673); 2, S. lividans 1326; 3, S. lividans 0783; 4, S. lividans TK24;5, S. coelicolor $A 3(2) ; 6, S$. coelescens; 7, S. humiferus; 8 , S. violaceolatus; 9 , S. caesius; 10 , S. cyanocolor; 11, S. tuirus; 12 , S. griseoruber.

Ltd, UK) were supplied coated with anti-mouse immunoglobulin $\mathrm{G}(\mathrm{IgG})$ sheep antibodies. Affinity coupling of $\mathrm{mAb}$ $43 \mathrm{H} 6$ was performed using the direct technique recommended by the manufacturers.

Recovery of spores using immunomagnetic particles. To examine the interaction of S. lividans 1326(pIJ673) spores and immunomagnetic beads, the beads were used either mAb $43 \mathrm{H} 6$ coated or with the sheep anti-mouse immunoglobulin coating as supplied, and were added to $1 \mathrm{ml}$ spore suspension in PBS. The mixture was incubated for $10 \mathrm{~min}$ at $37^{\circ} \mathrm{C}$ in a glass tube and a washing procedure was performed by placing the glass tube on a cobalt-samarium magnet. Beads and bead-spore complexes were drawn toward the inner wall of the tube close to the magnet for $2 \mathrm{~min}$. Whilst in this position beads were washed with excess PBS three times and once with sterile distilled water. Beads and spores were then resuspended in $50 \mu \mathrm{l}$ sterile distilled water. For examination by scanning electron microscopy drops of bead suspension were placed on glass coverslips that had been glued to scanning electron microscope studs using conductive glue. The stubs were allowed to dry overnight at room temperature, sputter coated with gold and examined under a Joel 840 scanning electron microscope operating at $25 \mathrm{kV}$.

To determine spore recovery from buffer suspensions a similar procedure was employed. However, the amount of beads used varied between experiments and after magnetic recovery, beads were resuspended in $100 \mu \mathrm{l}$ sterile water, sonicated briefly in a sonicating water bath and quantified by plate counting on R2YE media. In some experiments the magnetic beads were treated with the blocking agents bovine serum albumin $(2 \%$, $\mathrm{w} / \mathrm{v})$, hydrolysed gelatin $(2 \%, \mathrm{w} / \mathrm{v})$ and skimmed milk $(5 \%$, $w / v)$, prior to the recovery of $S$. lividans 1326 spores from PBS. In order to quantify the recovery of S. lividans 1326(pI J673) spores from soil, tenfold serial dilutions of $S$. lividans spores [either S. lividans 1326(pI J673) for use in sterile soil, or S. lividans
1326(pNW4) for use in non-sterile soil] were prepared in PBS. Soil samples $(10 \mathrm{~g})$ were placed in boiling tubes, autoclaved if required and wetted to $20 \%(\mathrm{w} / \mathrm{w})$ with distilled water. The appropriate spore suspension was added in $100 \mu$ l distilled water and after mixing, the microcosms were incubated overnight at $4{ }^{\circ} \mathrm{C}$.

To maximize the recovery of spores from soil using magnetic beads it was first necessary to produce a soil slurry to which beads could be added and then recovered by using a flowthrough device. Soil samples of $10 \mathrm{~g}$ were resuspended in $75 \mathrm{ml}$ sterile distilled water and treated with the repeated homogenization and centrifugation steps described above for determination of epitope stability up to the resuspension of the cell pellet in sucrose. The resulting pellet was instead resuspended in $6 \mathrm{ml}$ sterile distilled water. Beads $(2 \mathrm{mg})$, either $\mathrm{mAb} 43 \mathrm{H} 6$ coated or with sheep anti-mouse immunoglobulin coating as supplied, were added to each $6 \mathrm{ml}$ of soil suspension, mixed and incubated for $30 \mathrm{~min}$ at $37^{\circ} \mathrm{C}$. Beads were then captured by passing the suspension through a disposable plastic syringe which had a strong magnet attached to the side and a reservoir mounted on top. The soil slurry was introduced into the reservoir and allowed to travel slowly past the magnet, the speed being controlled by the gauge of the hypodermic needle on the end of the syringe. Extracted slurry was passed through the apparatus twice to maximize capture of the immunomagnetic beads from the large sample volumes employed. In order to capture spores from non-sterile soil $0.05 \%$ (v/v) Nonidet P40 $(\mathrm{BDH})$ was included in the capture buffer and $\mathrm{mAb} 43 \mathrm{H} 6$ coated beads were incubated in $5 \%(\mathrm{w} / \mathrm{v})$ skimmed milk prior to use. After extraction, the magnetic beads were washed with $6 \mathrm{ml}$ PBS whilst still captured, the syringe was removed and used together with its plunger to resuspend the captured particles in $1 \mathrm{ml}$ PBS. Of the $1 \mathrm{ml}, 0.5 \mathrm{ml}$ was plated directly on to $\mathrm{R} 2 \mathrm{YE}$ medium and the remaining $0.5 \mathrm{ml}$ serially diluted before plating on to the same medium.

The improvements to the immunocapture system, by blocking of beads with skimmed milk and addition of Nonidet P40, were subsequently applied to enhance the recovery of $S$. lividans 1326 (pNW4) spores from non-sterile soil. For spore isolation from non-sterile soil, the R2YE medium was replaced with actinomycete isolation agar (Difco) containing nystatin $\left(50 \mu \mathrm{g} \mathrm{ml}^{-1}\right)$ and cycloheximide $\left(50 \mu \mathrm{g} \mathrm{ml}^{-1}\right)$.

In experiments involving capture of spores from mixed suspensions in buffer, recovered spores were quantified by plate counts and were identified on the basis of spore and mycelium colouration or pigment production. S. griseoruber produced a grey/green spore mass, $S$. violaceolatus produced a purple pigment into the medium, $S$. spectabilis possessed a bright red/orange spore mass and S. lividans 1326(pNW4) $\left(p_{\mathrm{L}}, x y / E\right)$ was identified on the basis of catechol 2,3-dioxygenase (C23O) activity (Wipat et al., 1991).

Statistical analysis. Analysis of variance was performed on ELISA data using the Excel 4 software package (Microsoft).

\section{RESULTS}

\section{Production of mAbs}

$\mathrm{mAbs}$ were raised to spore surface antigens of $S$. lividans 1326(pI J673). Of 194 primary hybridomas from one fusion, 34 were found to secrete antibodies to $S$. lividans spores as judged by ELISA. One particular cell line, $43 \mathrm{H} 6$, produced an antibody that reacted primarily with spores from the immunizing strain, only showing crossreaction with a number of closely related species. $\mathrm{mAb}$ $43 \mathrm{H} 6$ reacted with all members of species cluster group 
21, with the exception of S. griseoruber (Fig. 1). The affinity of the antibody was highest for spores from $S$. lividans, $S$. coelicolor and $S$. coelescens. There was no significant reactivity (negative cut-off point 0.203 ) with spores from other Streptomyces cluster groups tested and no reactivity with spores from selected spore-forming soil organisms (Table 4). mAb $43 \mathrm{H} 6$ was isotyped and found to be of

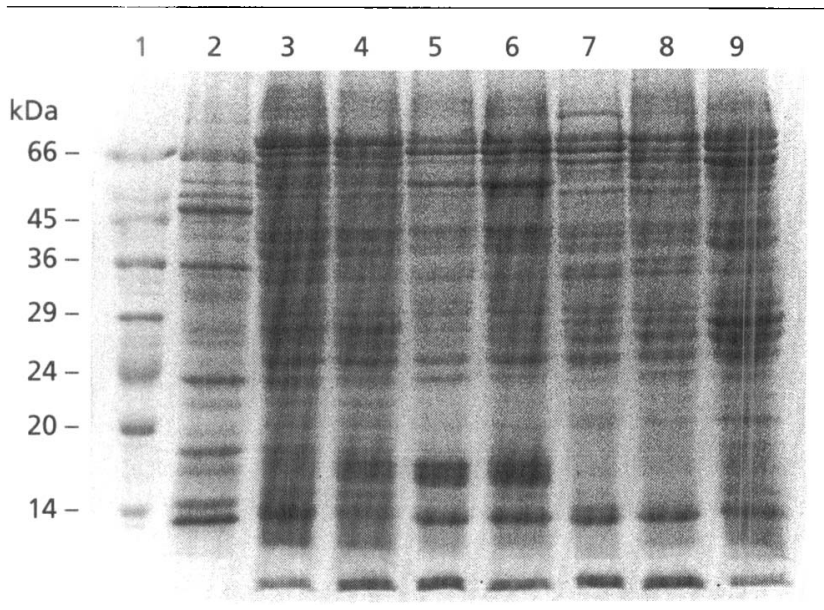

Fig. 2. SDS-PAGE of spore surface polypeptides from S. lividans 1326(p/J673) and other cluster 21 strains. Polypeptides were eluted from the surface of spores of S. lividans 1326(plJ673) and closely related strains from cluster 21 and subsequently separated and visualized by SDS-PAGE. Lanes: 1 , molecular mass markers; 2 , S. griseoruber; 3, S. cyanocolor; 4, S. caesius; 5, 5 . violaceolatus; 6,5 . humiferus; 7,5 . coelescens; 8 , S. coelicolor A3(2); 9, S. lividans 1326(plJ673).

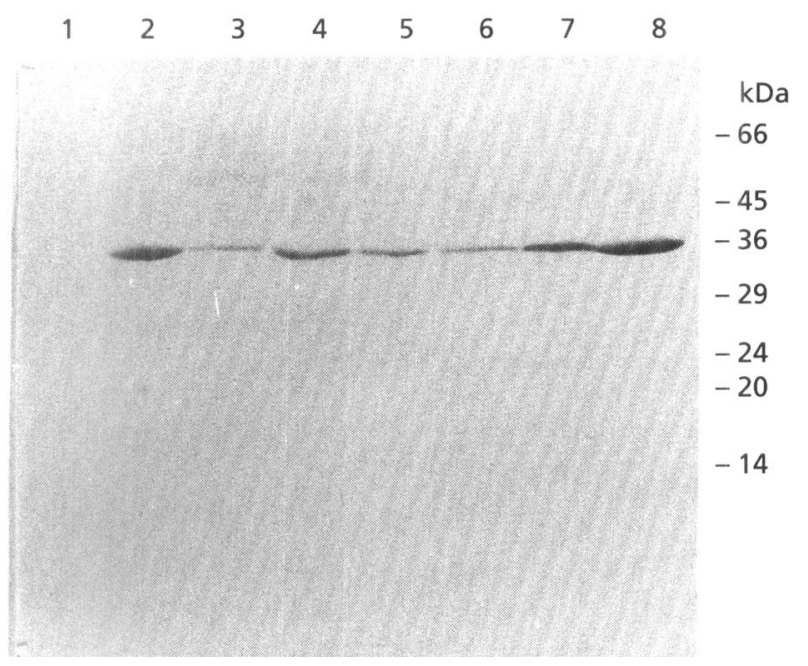

Fig. 3. Western blot analysis of spore surface polypeptides from S. lividans 1326(plJ673) and closely related strains from cluster 21. Polypeptides were eluted from the surface of spores of $S$. lividans 1326(plJ673) and other strains from cluster 21, separated by SDS-PAGE and transferred to a nitrocellulose filter. ELISA was performed on the immobilized polypeptides to visualize immunoreactive bands. Lanes: 1,5 . griseoruber; 2,5 . cyanocolor; 3, S. caesius; 4, S. violaceolatus; 5, S. humiferus; 6 , S. coelescens; 7, S. coelicolor A3(2); 8, S. lividans 1326(plJ673).
Table 4. Affinity of mAb $43 \mathrm{H} 6$ for spores from a range of streptomycetes and other microbial strains as determined by ELISA

$\mathrm{OD}_{490}$ data represent the means of at least three tests.

\begin{tabular}{|c|c|c|c|}
\hline Strain & $\begin{array}{c}\text { Streptomyces } \\
\text { cluster* }\end{array}$ & $\mathrm{OD}_{490}$ & SD \\
\hline S. griseus & $1 \mathrm{~A}$ & $0 \cdot 088$ & $0 \cdot 022$ \\
\hline S. coelicolor & $1 \mathrm{~A}$ & $0 \cdot 083$ & 0.012 \\
\hline S. scabies & 3 & $0 \cdot 058$ & $0 \cdot 005$ \\
\hline S. violaceus & 6 & $0 \cdot 175$ & 0.034 \\
\hline S. spectabilis & 10 & $0 \cdot 061$ & 0.009 \\
\hline S. matensis & 12 & $0 \cdot 060$ & $0 \cdot 007$ \\
\hline S. aureofaciens & 14 & 0.091 & 0.020 \\
\hline S. albus & 16 & 0.079 & 0.018 \\
\hline S. cacaoi & 16 & $0 \cdot 061$ & $0 \cdot 007$ \\
\hline S. murinus & 17 & $0 \cdot 163$ & 0.040 \\
\hline S. aqureus & 18 & $0 \cdot 091$ & $0 \cdot 015$ \\
\hline S. cyaneus & 18 & $0 \cdot 073$ & $0 \cdot 013$ \\
\hline S. lincolnensis & 19 & $0 \cdot 056$ & 0.006 \\
\hline S. vastus & 19 & 0.081 & 0.009 \\
\hline S. lividans 1326 & 21 & $>2.000$ & - \\
\hline S. lividans $T K 24$ & 21 & $1 \cdot 312$ & 0.057 \\
\hline S. roseiscleroticus & 22 & $0 \cdot 118$ & 0.060 \\
\hline S. toyacaenisis & 29 & $0 \cdot 081$ & 0.075 \\
\hline S. bygroscopicus & 32 & $0 \cdot 130$ & 0.054 \\
\hline S. griseoflavus & 37 & $0 \cdot 081$ & $0 \cdot 011$ \\
\hline S. birsutus & 37 & $0 \cdot 060$ & 0.012 \\
\hline S. bluensis & 39 & 0.075 & 0.008 \\
\hline S. violens & 40 & $0 \cdot 095$ & $0 \cdot 015$ \\
\hline S. albofaciens & 42 & $0 \cdot 083$ & $0 \cdot 013$ \\
\hline S. kanamyceticus & 42 & 0.092 & 0.018 \\
\hline S. rimosus & 42 & $0 \cdot 125$ & 0.016 \\
\hline S. tolypopharus & 53 & $0 \cdot 117$ & 0.036 \\
\hline S. griseoverticillatus & 58 & $0 \cdot 106$ & $0 \cdot 015$ \\
\hline S. columbiensis & 61 & $0 \cdot 130$ & $0 \cdot 054$ \\
\hline S. lavenducolor & 61 & 0.082 & 0.005 \\
\hline S. lavendulae & 61 & $0 \cdot 102$ & $0 \cdot 014$ \\
\hline S. fradiae & 68 & $0 \cdot 208$ & $0 \cdot 089$ \\
\hline Bacillus cereus & & $0 \cdot 148$ & $0 \cdot 014$ \\
\hline Bacillus megaterium & & $0 \cdot 113$ & $0 \cdot 012$ \\
\hline Bacillus subtilis & & $0 \cdot 148$ & $0 \cdot 014$ \\
\hline Bacillus stearothermophilus & & 0.079 & $0 \cdot 011$ \\
\hline Trichoderma viride & & $0 \cdot 145$ & $0 \cdot 012$ \\
\hline Penicillium chrysogenum & & $0 \cdot 186$ & $0 \cdot 013$ \\
\hline Fusarium culmorum & & $0 \cdot 028$ & 0.004 \\
\hline Negative controlt & & 0.095 & $0 \cdot 036$ \\
\hline Negative cut-off point $\ddagger$ & & $0 \cdot 203$ & \\
\hline
\end{tabular}

* Classification as Williams et al. (1983).

† Negative control wells contained S. lividans 1326 spores as antigen and received PBS-Tween in place of $\mathrm{mAb} 43 \mathrm{H} 6$.

$¥$ The negative cut-off point was defined as the mean of at least three negative controls plus three times the standard deviation (Ngo \& Lenhoff, 1985; Tjissen, 1985). 
IgG1 subclass, kappa type light chain. Western blot analysis and ELISA performed with mycelia cultured in vitro revealed that the antigenic polypeptide was also present on the surface of mycelia from cluster 21 streptomycetes (excluding $S$. griseoruber), but showed greatly reduced reactivity.

\section{SDSPAGE and Western blot analysis of Streptomyces spore polypeptides}

SDS-PAGE of purified spore polypeptides from S. lividans and other members of cluster 21 revealed a high degree of similarity for all species in the group except $S$. griseoruber, which shared only a few common polypeptides (Fig. 2). The differences evident by visually examining the protein profiles were confirmed by numerical analysis of electrophoregrams. Western blot analysis using $\mathrm{mAb} 43 \mathrm{H} 6$ as probe revealed the presence of a single immunoreactive polypeptide of approximately $37000 \mathrm{Da}$ for each species of cluster 21 except $S$. griseoruber (Fig. 3). Spore polypeptide profiles for species from other cluster groups were heterogeneous and no band corresponding to the $37000 \mathrm{Da}$ antigenic polypeptide was detected by Western blot analysis (data not shown).

\section{Epitope characterization and stability}

ELISA dot-blot analysis of spore extracts indicated that $\mathrm{mAb} 43 \mathrm{H} 6$ recognized a polypeptide epitope, and timebased removal of outer spore polypeptides showed that this epitope is located on or near the spore surface (results not shown).

The reactivity of spores taken from each of seven sporulation cycles, with mAb $43 \mathrm{H} 6$, as tested by ELISA, remained fairly constant. No significant difference was indicated by analysis of variance performed on replicate data between sporulation cycles $(P<0 \cdot 01)$. Following

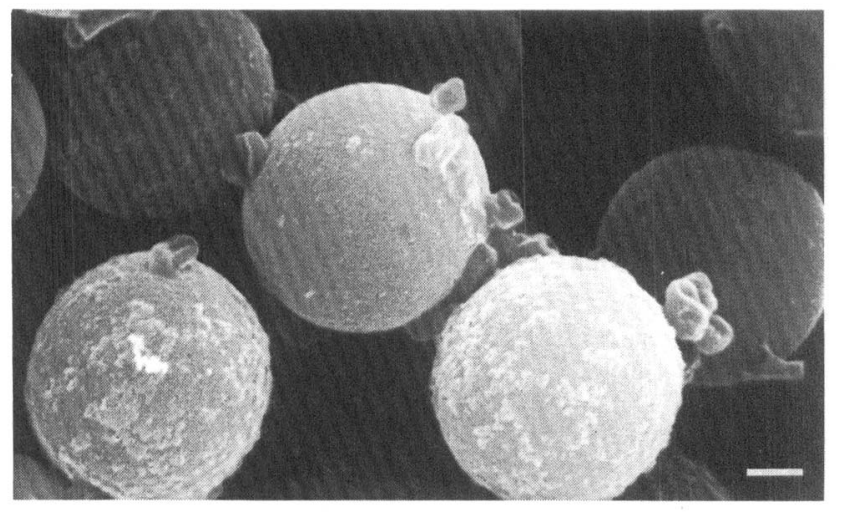

Fig. 4. Scanning electron micrograph showing details of the attachment of S. lividans 1326(plJ673) spores to mAb $43 \mathrm{H} 6$ coated beads. Bar, $1 \mu \mathrm{m}$.

incubation in sterile amended soil systems for 14 weeks the reactivity of spores with $\mathrm{mAb} 43 \mathrm{H} 6$ was compared with the original inoculum (data not shown). Analysis of variance was performed on ELISA data from three replicate samples and was found to indicate that reactivity was significantly lower with those spores derived from soil at the $95 \%$ confidence level $(P<0.05)$ but not significantly lower at the $99 \%$ confidence level $(P<0.01)$.

\section{Capture of spores from soil using magnetic beads}

Examination by scanning electron microscopy of magnetic beads that had been previously incubated in a spore suspension demonstrated the ability of $\mathrm{mAb} 43 \mathrm{H6}$ coated beads to bind S. lividans 1326(pI J673) spores (Fig. 4). Magnetic beads which had not received a mAb $43 \mathrm{H} 6$ coating did not show significant binding of spores (data not shown).

Table 5. Efficiency of S. lividans spore recovery from PBS by magnetic beads with increasing spore concentration

Magnetic beads $\left(0.6 \mathrm{mg} \mathrm{ml}^{-1}\right)$ were added to spore suspensions in PBS for which the c.f.u. $\mathrm{ml}^{-1}$ had been determined by plate counts (giving a bead:spore ratio from $1: 6$ to $15600: 1$ ). Spores were removed from bead-spore complexes by brief sonication and quantified by plate counts as described in Methods. Results are the means of at least two replicates.

\begin{tabular}{|c|c|c|c|c|}
\hline \multirow{2}{*}{$\begin{array}{l}\text { Original } \\
\text { concn of } \\
\text { spores } \\
\text { (c.f.u. } \mathrm{ml}^{-1} \text { ) }\end{array}$} & \multicolumn{2}{|c|}{$\begin{array}{c}\text { Recovery using } \\
\text { mAb 43H6-coated beads }\end{array}$} & \multicolumn{2}{|c|}{$\begin{array}{l}\text { Recovery using } \\
\text { non-coated beads }\end{array}$} \\
\hline & $\begin{array}{l}\text { Concn of } \\
\text { spores } \\
\text { recovered } \\
\text { (c.f.u. } \mathrm{ml}^{-1} \text { ) }\end{array}$ & $\begin{array}{l}\text { Percentage } \\
\text { recovery }\end{array}$ & $\begin{array}{l}\text { Concn of } \\
\text { spores } \\
\text { recovered } \\
\text { (c.f.u. } \mathrm{ml}^{-1} \text { ) }\end{array}$ & $\begin{array}{l}\text { Percentage } \\
\text { recovery }\end{array}$ \\
\hline $5 \times 10^{7}$ & $2 \cdot 18 \times 10^{6}$ & $4 \cdot 3$ & $4.20 \times 10^{5}$ & 0.84 \\
\hline $5 \times 10^{6}$ & $2.66 \times 10^{5}$ & $5 \cdot 32$ & $1.90 \times 10^{5}$ & $3 \cdot 20$ \\
\hline $5 \times 10^{5}$ & $4.20 \times 10^{4}$ & 8.40 & $1.50 \times 10^{4}$ & $3 \cdot 00$ \\
\hline $5 \times 10^{4}$ & $7 \cdot 10 \times 10^{3}$ & $28 \cdot 40$ & $2 \cdot 2,0 \times 10^{3}$ & $4 \cdot 40$ \\
\hline $5 \times 10^{3}$ & $1.60 \times 10^{3}$ & $32 \cdot 00$ & $2.60 \times 10^{2}$ & $5 \cdot 20$ \\
\hline $5 \times 10^{2}$ & $3.80 \times 10^{2}$ & $76 \cdot 00$ & $3.00 \times 10^{1}$ & 6.00 \\
\hline
\end{tabular}


Table 6. Effect of blocking agents applied to magnetic beads on the recovery of $S$. lividans 1326 spores from PBS

The original c.f.u. $\mathrm{ml}^{-1}$ was $5 \cdot 1 \times 10^{4}$ (as determined by plate counts); a total of $1.2 \mathrm{mg}$ of beads was used per $2 \mathrm{ml}$ reaction volume (bead:spore ratio 153:1). Results are the means of two replicates.

\begin{tabular}{|lllc|}
\hline Blocking agent & \multicolumn{1}{c|}{$\begin{array}{c}\text { Bead } \\
\text { coating }\end{array}$} & $\begin{array}{c}\text { Concn of } \\
\text { spores } \\
\text { recovered } \\
\left.\text { (c.f.u. } \mathbf{~ m}^{-1}\right)\end{array}$ & $\begin{array}{c}\text { Percentage } \\
\text { recovery }\end{array}$ \\
\hline None & mAb 43H6 & $1.97 \times 10^{4}$ & 38.62 \\
None & No mAb & $3.90 \times 10^{3}$ & 7.64 \\
BSA $(2 \%, w / v)$ & mAb 43H6 & $1.26 \times 10^{4}$ & 24.71 \\
BSA $(2 \%, w / v)$ & No mAb & $4.26 \times 10^{3}$ & 8.35 \\
Hydrolysed gelatin & mAb 43H6 & $2.70 \times 10^{2}$ & 0.53 \\
$(2 \%, w / v)$ & & & \\
Hydrolysed gelatin & No mAb & $1.55 \times 10^{2}$ & 0.30 \\
$(2 \%, w / v)$ & & & \\
Skimmed milk & mAb 43H6 & $2.05 \times 10^{4}$ & 40.19 \\
$(5 \%, w / v)$ & & & \\
Skimmed milk & No mAb & $9.55 \times 10^{2}$ & 1.87 \\
$(5 \%, w / v)$ & & & \\
\hline
\end{tabular}

The recovery of $S$. lividans $1326(\mathrm{pI} \mathrm{J673)}$ spores, by $\mathrm{mAb}$ 43H6-coated beads, from spore suspensions in buffer solutions increased with decreasing spore concentration, reaching $76 \%$ for an initial spore concentration of $5 \times 10^{2}$ (Table 5), whilst spore recovery by beads which had not received a mAb $43 \mathrm{H} 6$ coating reached $6 \%$ using the same initial concentration. Spore recovery by mAb $43 \mathrm{H} 6-$ coated beads was also increased by increasing the bead concentration (data not shown).

To facilitate magnetic bead recovery from soil it was necessary to employ a flow-through capture device (see
Table 8. Capture of S. lividans 1326(pNW4) spores from non-sterile soil using mAb 43H6-coated magnetic beads using skimmed milk blocking agent and Nonidet P40 detergent

S. lividans $1326(\mathrm{pNW} 4)$ spores were recovered from non-sterile soil samples which had been seeded with a range of spore concentrations and incubated overnight at $4{ }^{\circ} \mathrm{C}$. Spore concentrations were quantified in terms of c.f.u. $\mathrm{ml}^{-1}$ by plate counts prior to inoculation into soil. $\mathrm{mAb} 43 \mathrm{H} 6$-coated beads were used at a concentration of $0.33 \mathrm{mg}$ ( $\mathrm{ml}$ soil slurry) ${ }^{-1}$ (bead:spore ratio varied from $84500: 1$ to $1: 118$ ). Results are the means of two replicates.

\begin{tabular}{|lcc|}
\hline $\begin{array}{l}\text { Concn of } \\
\text { spores } \\
\text { seeded } \\
\text { [c.f.u. } \\
\text { (g dry wt }_{\text {soil) }}^{-1} \text { ] }\end{array}$ & $\begin{array}{c}\text { Concn of } \\
\text { spores } \\
\text { recovered } \\
\text { [c.f.u. } \\
\text { (g dry wt } \\
\text { soil) }\end{array}$ & $\begin{array}{c}\text { Percentage } \\
\text { recovery }\end{array}$ \\
\hline 10 & 0 & \\
$10^{2}$ & 1 & 0 \\
$10^{3}$ & 16 & 1.00 \\
$10^{4}$ & $1.23 \times 10^{2}$ & 1.60 \\
$10^{5}$ & $4.44 \times 10^{3}$ & 4.40 \\
$10^{6}$ & $3.42 \times 10^{4}$ & 3.40 \\
$10^{7}$ & $2.36 \times 10^{5}$ & 2.36 \\
$10^{8}$ & $8.78 \times 10^{4}$ & 0.09 \\
\hline
\end{tabular}

Methods). Using such apparatus with $0.6 \mathrm{mg} \mathrm{mAb} 43 \mathrm{H} 6-$ coated beads $\mathrm{ml}^{-1}$ the recovery was $30.5 \%$ for spores seeded at a concentration of $10^{5}$ ( $\mathrm{g}$ sterile soil) ${ }^{-1}$. However, using beads without $\mathrm{mAb} 43 \mathrm{H} 6$ resulted in a $16.5 \%$ recovery at the same initial spore concentration. In an effort to reduce such non-specific spore binding, various blocking agents were applied to beads (Table 6). Incubation of beads in skimmed milk $(5 \%, \mathrm{w} / \mathrm{v})$ prior to use had little effect on the specific binding of $\mathrm{mAb} 43 \mathrm{H} 6$

Table 7. Effect of washing and inclusion of non-ionic detergents in buffer solutions on non-specific binding of spores of S. lividans 1326

The initial concentration of spores (c.f.u. $\mathrm{ml}^{-1}$ ) in the diluted suspension is shown and was determined by plate counts. A sample of $0.6 \mathrm{mg}$ of beads was used per $\mathrm{ml}$ of spore suspension (bead:spore ratio $281: 1$ ). Spore recovery was performed in a total volume of $1 \mathrm{ml}$ and was quantified by plate counts. Results are the means of two replicates.

\begin{tabular}{|c|c|c|c|c|}
\hline Buffer & $\begin{array}{c}\text { Bead } \\
\text { coating }\end{array}$ & $\begin{array}{c}\text { Initial concn } \\
\text { of spores } \\
\text { (c.f.u. } \mathrm{ml}^{-1} \text { ) }\end{array}$ & $\begin{array}{l}\text { Concn of } \\
\text { spores } \\
\text { recovered } \\
\text { (c.f.u. } \mathrm{ml}^{-1} \text { ) }\end{array}$ & $\begin{array}{c}\text { Percentage } \\
\text { recovery }\end{array}$ \\
\hline PBS & $\mathrm{mAb} 43 \mathrm{H} 6$ & $2.78 \times 10^{4}$ & $6.8 \times 10^{3}$ & $24 \cdot 4$ \\
\hline PBS & No $m A b$ & $2 \cdot 78 \times 10^{4}$ & $1 \cdot 1 \times 10^{3}$ & 3.96 \\
\hline PBS $/ 0.05 \%(v / v)$ Tween 20 & $\mathrm{mAb} 43 \mathrm{H} 6$ & $2 \cdot 78 \times 10^{4}$ & $5 \cdot 14 \times 10^{3}$ & $18 \cdot 48$ \\
\hline PBS $/ 0.05 \%(\mathrm{v} / \mathrm{v})$ Tween 20 & No $m A b$ & $2 \cdot 78 \times 10^{4}$ & $1.27 \times 10^{3}$ & $4 \cdot 59$ \\
\hline PBS $/ 0.05 \%(v / v)$ Nonidet P40 & $\mathrm{mAb} 43 \mathrm{H} 6$ & $2 \cdot 78 \times 10^{4}$ & $7 \cdot 26 \times 10^{3}$ & $26 \cdot 10$ \\
\hline PBS $/ 0.05 \%(\mathrm{v} / \mathrm{v})$ Nonidet P40 & No mAb & $2 \cdot 78 \times 10^{4}$ & $7 \cdot 20 \times 10^{2}$ & $2 \cdot 59$ \\
\hline
\end{tabular}


Table 9. Immunomagnetic recovery of S. lividans $1326(\mathrm{pNW} 4)$ spores from mixed spore suspensions in PBS buffer

S. lividans 1326 ( $\mathrm{pNW} 4$ ) spores were recovered by using mAb 43H6-coated magnetic beads from mixed spore suspensions in PBS (see Methods). The capture volume was $1 \mathrm{ml}$ for each mixture and a total of $0.3 \mathrm{mg} \mathrm{mAb} 43 \mathrm{H} 6$-coated beads were used in each recovery (bead:spore ratio 4:1). Results are the means of at least two replicates.

\begin{tabular}{|c|c|c|c|}
\hline & $\begin{array}{c}\text { Initial } \\
\text { spore concn } \\
\text { (c.f.u. } \mathrm{ml}^{-1} \text { ) }\end{array}$ & $\begin{array}{c}\text { Concn of } \\
\text { spores } \\
\text { recovered } \\
\text { (c.f.u. } \mathrm{ml}^{-1} \text { ) }\end{array}$ & $\begin{array}{l}\text { Percentage } \\
\text { recovery }\end{array}$ \\
\hline S. lividans $1326(\mathrm{pNW})$ & $10^{6}$ & $1.2 \times 10^{5}$ & $12 \cdot 5$ \\
\hline S. lividans $1326(\mathrm{pNW})$ & $10^{6}$ & $8.7 \times 10^{4}$ & $8 \cdot 7$ \\
\hline$\stackrel{+}{\text { S. violaceolatus }}$ & $10^{6}$ & $2: 5 \times 10^{4}$ & $2 \cdot 5$ \\
\hline S. lividans $1326(\mathrm{pNW} 4)$ & $10^{6}$ & $1 \cdot 3 \times 10^{5}$ & $13 \cdot 1$ \\
\hline S. griseoruber & $10^{6}$ & $3 \cdot 2 \times 10^{3}$ & $0 \cdot 3$ \\
\hline $\begin{array}{l}\text { S. lividans 1326(pNW4) } \\
+\end{array}$ & $10^{6}$ & $6.8 \times 10^{4}$ & 6.8 \\
\hline $\begin{array}{l}\text { S. violaceolatus } \\
+\end{array}$ & $10^{6}$ & $1 \cdot 2 \times 10^{4}$ & $1 \cdot 2$ \\
\hline $\begin{array}{c}\text { S. griseoruber } \\
+\end{array}$ & $10^{6}$ & $1.3 \times 10^{3}$ & $0 \cdot 1$ \\
\hline S. spectabilis & $10^{6}$ & $7 \cdot 1 \times 10^{2}$ & $0 \cdot 07$ \\
\hline $\begin{array}{c}\text { S. lividans } 1326(\mathrm{pNW} 4) \\
+\end{array}$ & $10^{6}$ & $1.2 \times 10^{5}$ & $12 \cdot 5$ \\
\hline S. spectabilis & $10^{6}$ & $1.3 \times 10^{3}$ & $0 \cdot 13$ \\
\hline
\end{tabular}

beads, whilst reducing the level of spore binding shown by beads which had not received the mAb $43 \mathrm{H} 6$ coating. In addition the effect of adding detergents to buffer solutions was assessed (Table 7). Inclusion of Noniclet P40 $(0.05 \%, \mathrm{v} / \mathrm{v})$ in the magnetic capture buffer was similarly found to reduce the level of spore capture by beads with no mAb $43 \mathrm{H} 6$ coating.

Recovery of S. lividans $1326(\mathrm{pNW} 4)$ spores from nonsterile soil reached a maximum of $4.4 \%$ of a seeded concentration of $10^{5} \mathrm{~g}^{-1}$ (Table 8 ), a value significantly lower than that from sterile soil. This was possibly due to spores from cross-reacting cluster 21 streptomycetes competing with those of the released strain in non-sterile soil. Indeed a number of $\mathrm{XylE}^{-}$streptomycetes were evident on the plate cultures of spores which had been magnetically recovered (results not shown). In order to investigate the effect of cross-reactivity on the recovery of $S$. lividans $1326(\mathrm{pNW} 4)$, spores from mixed spore suspensions were examined. $S$. lividans spores were magnetically recovered from buffer suspensions in which they had been mixed with spores from related species from cluster 21 and with those from clusters outside this group (Table 9). Recovery of S. lividans 1326(pNW4) decreased significantly in the presence of cluster 21 strains, such as $S$. violaceolatus, but not $S$. griseoruber. Strains from other cluster groups, for example $S$. spectabilis (cluster 10) had little effect on recovery. Recovery values correlated with the reactivities shown by $\mathrm{mAb} 43 \mathrm{H} 6$ against each spore type in ELISA.

\section{DISCUSSION}

An approach to developing immunological methods for the detection and recovery of $S$. lividans has been to raise $\mathrm{mAbs}$ to spore surface determinants. However, given the similarity of SDS-PAGE spore polypeptide profiles for most members of cluster group 21, mAbs have been obtained using intact spores of $S$. lividans, rather than a particular spore polypeptide, as immunogen. From all the $\mathrm{mAb}$-producing cell lines screened, none produced an antibody that was unique to $S$. lividans, presumably due to the fact that there are few differences in spore surface polypeptides between members of the cluster group. However, species group specific $\mathrm{mAbs}$ were obtained, of which $\mathrm{mAb} 43 \mathrm{H} 6$ reacted with a polypeptide epitope of about $37000 \mathrm{Da}$ present in spores of all cluster 21 members except $S$. griseoruber. Interestingly this species, designated as the representative member of the group (Williams et al., 1983), exhibited a markedly different spore polypeptide profile to other members. mAb $43 \mathrm{H} 6$ showed greatest affinity for the spores from the immunizing strain, S. lividans 1326(pIJ673), but also reacted strongly with spores from some other members. 
Differences in the extent of ELISA reactivity of $\mathrm{mAb}$ $43 \mathrm{H} 6$ with spores from different members of the group may be attributable to the amount of the polypeptide antigen within the spore or to a variation in the configuration of the antigen within each strain. Reactivity of the $\mathrm{mAb}$ with mycelium suggests the presence of the antigenic determinant in the mycelial wall. Interestingly the ELISA results supported the grouping of species within cluster 21 as based on a numerial taxonomic study of phenotypic characteristics (Williams et al., 1983). $S$. caesius, S. bumiferus (Actinopycnidium caeruleum), $S$. cyanocolor, $S$. lividans, $S$. coelescens and $S$. violaceolatus formed a close group and reacted strongly with $\mathrm{mAb} 43 \mathrm{H} 6$. Data for $S$. coelicolor A3(2) were not available in the study of Williams et al. (1983).

An important consideration for $\mathrm{mAbs}$ that are intended for use in detecting specific micro-organisms in the environment is the stability of the target antigen. This is particularly applicable to streptomycetes, which exhibit a high degree of spontaneous mutation and genomic rearrangements (Altenbucher \& Cullum, 1984; Betzler et al., 1987; Dyson \& Schrempf, 1987). Furthermore, modulation in nutrient status, as encountered in natural environments, has been shown to alter accessibility and expression of surface antigens in both Gram positive and Gram negative bacteria (McGroaty \& Rivera, 1990; Nelson et al., 1991; Smith et al., 1991) in turn affecting antibody binding. The affinity of $\mathrm{mAb} 43 \mathrm{H} 6$ for spores isolated from sterile soil was lower than for spores from R2YE medium. It may be that the antigen concentration is lower in soil. Alternatively the spore isolation procedure may have affected spore surface structure. However, the stability of the antigen may also depend on the morphological state of the spore. Guijarro et al. (1983) have reported a degradation pattern of spore proteins which commences on spore germination and this may alter the antigen configuration.

Whilst reacting with spores from cluster $21, \mathrm{mAb} 43 \mathrm{H} 6$ showed no significant affinity for spores from other cluster groups nor for spores from the other bacteria and soil-borne fungi tested. Such species group specificity was exploited to develop a selective capture procedure for Streptomyces spores from soil utilizing immunomagnetic beads. Anti-mouse IgG pre-coated magnetic beads were chosen, rather than uncoated beads, since they were more effective in spore recovery when subsequently coated with secondary antibody. However the pre-coated beads without $\mathrm{mAb} 43 \mathrm{H} 6$ appeared to recover some spores. This may be due to non-specific binding of spores to beads and/or trapping of spores between beads during magnetic capture. Non-specific binding of bacteria to beads has been reported by other workers (Lund et al., 1988; Morgan et al., 1991). Inclusion of the non-ionic detergent Nonidet P40 in the recovery buffer reduced the nonspecific reaction of pre-coated beads alone and enhanced recovery of spores, when beads were subsequently coated with $\mathrm{mAb} 43 \mathrm{H} 6$, without affecting viability. This contrasts with the reduction in cell viability encountered when the detergent was used in immunocapture of bacterial cells (Morgan et al., 1991). Treatment of beads with blocking agents, such as skimmed milk, also reduced non-specific binding events. Such improvements in the recovery procedure permitted the capture of spores from both sterile and non-sterile soil. Recovery of S. lividans spores from non-sterile soil was significantly lower than that from sterile soil. This may be attributable to 'competition' from naturally-occurring cluster 21 members in the soil. Indeed when other cluster 21 strains were added to capture buffers there was a resultant decrease in the recovery of $S$. lividans spores. Whilst addition of strains from other cluster groups had little effect on recovery values.

Such an immunocapture technique offers a rapid and convenient means of partially recovering and concentrating target Streptomyces cluster 21 spores from crude soil samples for the subsequent application of specific detection techniques that may require cleaner samples. Moreover, if used in conjunction with an appropriate marker system, for example the $x y l E$ system for $S$. lividans (Wipat et al., 1991), specific marked strains could be identified directly.

\section{ACKNOWLEDGEMENTS}

We gratefully acknowledge financial support from the Polytechnics National Advisory Board. We thank J. Kaye for technical assistance and S. Parry and G. P. Sharples for assistance with scanning electron microscopy. We also thank C. A. Hart, Department of Medical Microbiology, University of Liverpool for guidance in the production of the monocional antibodies.

\section{REFERENCES}

Altenbucher, J. \& Cullum, J. (1984). DNA amplification and an unstable arginine gene in Streptomyces lividans 66. Mol \& Gen Genet 195, 134-138

Betzler, M., Dyson, P. \& Schrempf, H. (1987). Relationship of an unstable $\operatorname{argG}$ gene to a 5.7-kilobase amplifiable DNA sequence in Streptomyces lividans 66. J Bacteriol 169, 4804-4810.

Clark, M. \& Waldmann, H. (1985). Production of murine monoclonal antibodies. In Methods in Haematology, pp. 1-19. Edited by P. Beverly \& C. Livingston. London: Academic Press.

Cresswell, N., Herron, P.R., Saunders, V.A. \& Wellington, E. M. H. (1992). The fate of introduced streptomycetes, plasmid and phage populations in a dynamic soil system. J Gen Microbiol 138, 659-666.

Cross, T. \& Spooner, D. F. (1963). The serological identification of streptomycetes by agar diffusion techniques. J Gen Microbiol 33, 275-282.

Dyson, P. \& Schrempf, H. (1987). Genetic instability and DNA amplification in Streptomyces lividans 66. J Bacteriol 169, 4796-4803.

Gates, J. E. \& Pham, K. D. (1979). An indirect fluorescent antibody staining technique for determining population levels of Thiobacillus ferrooxidans in acid mine drainage waters. Microb Ecol 5, 121-127.

Guijarro, J. A., Suarez, J. E., Salas, J. A. \& Hardisson, C. (1983). Pattern of protein degradation during germination of Streptomyces antibioticus spores. Can J Microbiol 29, 637-643.

Guijarro, J., Santamaria, R., Schauer, A. \& Losick, R. (1988). Promoter determining the timing and spatial localization of transcription of a cloned Streptomyces coelicolor gene encoding a spore-associated polypeptide. J Bacteriol 170, 1895-1901. 
Harlow, E. \& Lane, D. (1988). Antibodies - A Laboratory Manua!. Cold Spring Harbor, NY: Cold Spring Harbor Laboratory.

Hopwood, D. A., Bibb, M. J., Chater, K. F., Kieser, T., Bruton, C. J., Kieser, H. M., Lydiate, D. J., Smith, C. D., Ward, J. M. \& Schempf, H. (1985). Genetic Manipulation of Streptomyces: A Laboratory Manual. Norwich: John Innes Foundation.

Laemmli, U. K. (1970). Cleavage of structural proteins during the assembly of the head of bacteriophage T4. Nature 227, 680-685.

Levasseur, S., Husson, M.-O., Leitz, R., Merlin, F., Laurent, F., Peladan, F., Drocourt, J. L., Leclec, H. \& Van Hoegaerden, M. (1992). Rapid detection of members of the family Enterobacteriaceae by a monoclonal antibody. Appl Environ Microbiol 58, 1524-1529.

Lund, A., Hellemann, A. L. \& Vartdal, F. (1988). Rapid isolation of $\mathrm{K}^{2} 8^{+}$Escherichia coli by using immunomagnetic particles. J Clin Microbiol 26, 2572-2575.

Mason, J. \& Burns, R. G. (1990). Production of a monoclonal antibody specific for a Flavobacterium species isolated from soil. FEMS Microbiol Lett 73, 299-308.

Mayfield, C. I., Williams, S. T., Ruddick, S. M. \& Hatfield, H. L. (1972). Studies on the ecology of actinomycetes in soil IV. Observations on the form and growth of streptomycetes in soil. Soil Biol Biochem 4, 79-91.

McGroaty, E. J. \& Rivera, M. (1990). Growth-dependent alteration in production of serotype-specific and common antigen lipopolysaccharides in Pseudomonas aeruginosa PAO1. Infect Immun 57, 1030-1037.

Morgan, J. A. W., Winstanley, C., Pickup, R. W., Jones, J. G. \& Saunders, J. R. (1989). Direct phenotypic and genotypic detection of a recombinant pseudomonad population released into lake water. Appl Environ Microbiol 55, 2537-2544.

Morgan, J. A. W., Winstanley, C., Pickup, R. W. \& Saunders, J. R. (1991). Rapid immunocapture of Pseudomonas putida cells from lake water by using bacterial flagella. Appl Environ Microbiol 57, 503-509.

Nelson, D., Bathgate, A. J. \& Poxton, I. R. (1991). Monoclonal antibodies as probes for detecting lipopolysaccharide expression on Escherichia coli from different growth conditions. J Gen Microbiol 137, 2741-2751.

Ngo, T. T. \& Lenhoff, H. M. (1985). Enzyme-mediated Immunocissay. New York: Plenum Press.

Ramos-González, M. I., Ruiz-Cabello, F., Brettar, I., Garrido, F. \& Ramos, J. L. (1992). Tracking genetically engineered bacteria: monoclonal antibodies against surface determinants of soil bacterium Pseudomonas putida 2440. J Bacteriol 174, 2978-2985.
Ridell, M. \& Williams, S. T. (1983). Serotaxonomic analysis of some Streptomyces and related organisms. J Gen Microbiol 129, 2857-2861.

Ridell, M., Wallerstrom, G. \& Williams, S.T. (1986). Immunodiffusion analyses of phenetically defined strains of Streptomyces, Streptoverticillum and Nocardiopsis. Syst Appl Microbiol 8, 24-27.

Smith, A. W., Wilton, J., Clark, S. A., Alpar, O., Melling, J. \& Brown, M. R. W. (1991). Production and characterization of monoclonal antibodies to outer membrane proteins of Pseudomonas aeruginosa grown in iron depleted media. J Gen Microbiol 137, $227-236$.

Strayer, R. F. \& Tiedje, J. M. (1978). Application of the fluorescent antibody technique to the study of methanogenic bacterium in lake sediments. Appl Environ Microbiol 35, 192-197.

Tjissen, P. (1985). Laboratory Techniques in Biocbemistry and Molecular Biology, vol. 15, Practice and Theory of Enzyme Immunoassays. New York: Elsevier.

Towbin, H., Staehelin, T. \& Gordon, J. (1979). Electrophoretic transfer of proteins from SDS and acid/urea polyacrylamide gels to nitrocellulose sheets, procedure and some applications. Proc Natl Acad Sci US A 76, 4350-4354.

Ward, J. M., Janssen, G. R., Keiser, T., Bibb, M. J. \& Bibb, M. J. (1986). Construction and characterisation of a series of multi-copy promoter-probe vectors for Streptomyces using the aminoglycoside phosphotransferase gene from $T n 5$ as indicator. Mol \& Gen Genet 203, 468-478.

Wellington, E. M. H., Cresswell, N. \& Saunders, V. A. (1990). Growth and survival of streptomycete inoculants and extent of plasmid transfer in sterile and nonsterile soil. Appl Environ Microbiol 56, 1413-1419.

Williams, S.T., Goodfellow, M., Alderson, G., Wellington, E. M. H., Sneath, P. H. A. \& Sackin, M. J. (1983). Numerica classification of Streptomyces and related genera.J Gen Microbiol 129 , 1743-1813.

Wipat, A., Wellington, E. M. H. \& Saunders, V. A. (1991). Streptomyces marker plasmids for monitoring survival and spread of streptomycetes in soil. Appl Environ Microbiol 57, 3322-3330.

Wright, S. F., Morton, J. B. \& Sworobuk, J. E. (1987). Identification of a vesicular-arbuscular mycorrhizal fungus by using monoclonal antibodies in an enzyme linked immunosorbent assay. Appl Environ Microbiol 53, 2222-2225.

Received 19 November 1993; revised 4 March 1994; accepted 10 March 1994. 